\title{
Investigation of tribological and mechanical properties of metal bearings
}

\author{
BEKIR SADIK ÜNL ̈̈ \\ Department of Machinery, Vocational High School, Celal Bayar University, 45400-Turgutlu-Manisa, Turkey
}

MS received 18 August 2008; revised 2 September 2009

\begin{abstract}
Copper, aluminum and tin-lead based alloys are widely used as journal bearing materials in tribological applications. Bronze and brass are widely used as journal bearing materials for copper based alloys. Zamacs find applications as journal bearing materials for zinc based alloys, while duralumines are chosen as journal bearing materials for aluminum based alloys. In addition, white metals are widely used as journal bearing materials for tin-lead based alloys. These alloys ensure properties expected from journal bearings. In this study, tribological and mechanical properties of these journal bearings manufactured by metals were investigated. SAE 1050 steel shaft was used as counter abrader. Experiments were carried out in every 30 min for a total of $150 \mathrm{~min}$ by using radial journal bearing wear test rig.
\end{abstract}

Keywords. Non-ferrous metals; bearings; tribology; mechanical properties.

\section{Introduction}

In the past few years, wood, iron and skin have been used as journal bearing materials. Later, brass, bronze and white metal have also found some applications. Currently, in addition to these bearing materials, aluminum and zinc based materials are used as journal bearing materials. With technological improvements, self-lubricated sintered bearings and plastic materials are used where continuous lubricating is impossible. Therefore, it is essential that the bearing material be chosen depending upon area of application.

Wear resistance is one of the most important properties that journal bearings should possess. There are several studies and investigations dealing with wear resistance improvements of these materials (Eyre 1991; Schatt and Wieters 1997; Enomoto and Yamamoto 1998; Ünlü 2004).

Copper based materials are widely used as bearing materials because they have high thermal and electrical conductivity, self-lubrication property, good corrosion and wear resistance (Schmidt and Schmidt 1993; Paulo 2000). The effect of tin on wear in copper based materials is important. Copper based tin bronzes are used as bearing materials to have a high wear resistance (Prasad 1997). Friction and wear properties of these materials can be improved by adding tin (Backensto 1990). Tin bronze (90\% $\mathrm{Cu}$ and $10 \% \mathrm{Sn})$ is the most suitable bearing material under corrosive conditions, at high temperatures and high loads (Pratt 1973).

Zinc based alloys were used instead of bronze during World War II as journal bearing materials to compensate

(bekir.unlu@bayar.edu.tr) for copper deficiency in Germany (Pürçek 1994). Zn based alloys are used due to high strength, high hardness and good friction properties in several engineering applications. Tribological properties of $\mathrm{Al}$ and $\mathrm{Cu}$ alloys are better than those of pure $\mathrm{Zn}$ and $\mathrm{Zn}-\mathrm{Al}$ alloys. Tribological and mechanical properties of $\mathrm{Zn}-\mathrm{Al}$ alloys can be improved by heat treatment and by $\mathrm{Mn}, \mathrm{Si}$, and $\mathrm{Cu}$ addition. Therefore, these alloys can be used as journal bearing materials (Hanna et al 1997). Zn based alloys are used because of their good physical, mechanical and tribological properties, low cost, high wear resistance as journal bearing materials. Tribological properties of $\mathrm{ZnAlCuSi}$ alloy were higher than those of $\mathrm{ZnAl}$ and bronze (Pürçek et al 1999; Savaşkan et al 2002; Çuvalcı and Baş 2004). ZA27 is an alloy with good tribological properties. If $2.5 \% \mathrm{Si}$ was added to alloys, wear resistance would increase (Harmsen et al 1996). These alloys are important for high loading, low speed applications as journal bearing materials. Tribological properties of these alloys are higher than those of bronze materials. They are preferred to Al alloy, and cast iron due to high non-seizure, mechanical and wear resistance property for journal bearing applications. Hardness decreases, but friction coefficient and wear resistance increase by graphite addition (Sharma et al 1998).

$\mathrm{Al}$ alloys containing $\mathrm{Cu}, \mathrm{Mg}$ and $\mathrm{Mg}, \mathrm{Si}$; $\mathrm{Sn}$ are used as bearing materials (Lepper et al 1997). Until the early $1940 \mathrm{~s}$, white metal was used and then Al alloys were used as bearing materials (Niinomi et al 1997). Al alloys can be used in applications where corrosion is a problem. Wear resistance of $\mathrm{Si}$ added $\mathrm{Al}$ alloys is higher than that of the other Al alloys (Haque and Sharif 2001). Al-Si alloys have good castability, thermal conductivity, and 
weldability, high strength and excellent corrosion resistance. They are used in pistons and bearings due to these properties. Si particles can be distributed into structure uniformly, thus material hardness increases (Prasad and Rohatgi 1987). In addition, Al-Mg-Si alloys are used in tribology applications due to excellent sliding and mechanical properties such as high strength, high deformability and good wear resistance (Liu et al 1999).

Tribo-materials used have embability and high wear resistance for crank shaft in automobiles. These bearings have lead, tin, aluminium and copper. These elements are coated to steel bearing due to their superior wear properties (Upadhyaya et al 1997; Dawson 1998; Enomoto and Yamamoto 1998).

Lead and tin based white metal alloys are used due to their antifriction property as bearing materials. These alloys are produced by casting and spray deposition method. These casting alloys contain intermetallic phase. The process variables during spray forming of babbit bearing metal alloy strongly influence the microstructure and porosity of the spray deposits. The wear rate of the spray-formed alloy is lower than that of the as-cast alloy. Wear properties of the spray-formed alloy are attributed to the decreased intermetallic phases and modification in the microstructure of the eutectic phases (Upadhyaya et al 1997). $\mathrm{SnPbCuSb}$ (white metal) alloys are important due to non-seizure and good wear resistance as journal bearing material (Ünlü 2004).

Journal bearing materials are expected to have several properties such as low friction coefficient, high load capacity, high heat conductivity, compatibility, high wear and corrosion resistance. These properties directly affect the fatigue and wear life (Pratt 1973; Backensto 1990; Prasad 1997). White metal (babbit), cast iron, bronze, aluminum, and zinc-aluminum-based materials have been widely used as journal bearings due to their superior wear properties (Barhust 1989; Çuvalcı and Baş 2004; Zeren 2007). Some metal bearings provide these properties. In this study, friction coefficient, temperature values and wear losses of bearing-journal samples were determined by wearing (Atik et al 2001; Ünlü and Atik 2007) on radial journal bearing wear test rig designed specially for this purpose manufactured by $\mathrm{CuSn} 10$ bronze, CuZn30 brass, $\mathrm{ZnAl}$ zamac, $\mathrm{AlCuMg} 2$ duralumine, and $\mathrm{SnPbCuSb}$ white metal for $\mathrm{Cu}, \mathrm{Zn}, \mathrm{Al}$, and $\mathrm{Sn}-\mathrm{Pb}$ based alloys. These alloys are especially used in automotive and machine element applications as journal bearing materials (Ünlü 2004).

\section{Experimental}

\subsection{Preparation of experimental materials}

In this study, CuSn10 bronze, CuZn30 brass, $\mathrm{ZnAl}$ zamac, $\mathrm{AlCuMg} 2$ duralumine, and $\mathrm{SnPbCuSb}$ white metal specimens were used as journal bearing and SAE 1050 was used as shaft. The chemical composition of the journal materials used in the experiments is given in table 1 . The chemical composition of the bearings materials used in the experiments is given in table 2. Dimensions of bearing specimens were as follows: inner diameter $10^{+0.05}$ $\mathrm{mm}$, width $10 \mathrm{~mm}$, and outer diameter, $15 \mathrm{~mm}$.

The specimens were worn by radial journal bearing wear test rig under lubricated condition. The wear losses were measured under lubricated conditions of $20 \mathrm{~N}$ loads, $1500 \mathrm{rpm}(v=0.785 \mathrm{~m} / \mathrm{s}$ velocity $)$ and every $30 \mathrm{~min}$ for $2.5 \mathrm{~h}$ (7065 $\mathrm{m}$ sliding distance). Lubricating was accomplished by using SAE 90 gear oil. The microstructures of wear surfaces were photographed using optical and scanning electron microscope.

Tensile, compressive, notch impact, three-point bending, radial fracture and hardness were performed using ALŞA type tensile test rig depending on TS-138, and TS269 (Turkish Standard) for mechanical properties. Moreover, the hardness was measured using a SADT HARTIP3000 type.

\subsection{Radial journal bearing wear test rig}

Bearing materials in journal bearings were generally selected from materials which had lower wear strength than the shaft material, thereby lowering the wearing of the shaft significantly. For this reason, journal bearing wear test apparatus were designed to examine the wearing of bearing materials. In this study, a special bearing wear test apparatus has been designed to examine the wearing behaviour of bearing material and the shaft together. Therefore, it is possible to investigate different bearing and shaft materials and the effects of heat treatments on these materials. Such a mechanism provides wear of bearings rather than using standard methods as this is more appropriate (Atik et al 2001).

The system was formed by a weight applied by a rigid bar, a steel bar connected to the bearing from a distance and a comparator. Friction coefficient was determined from the friction force formed along the rotating direction of the bearing and from the movement of the steel bar connected to the bearing (Ünlü and Atik 2007). Radial wear test rig is illustrated in figure 1.

In the experiments under lubricated conditions, very little movement took place for high comparator's spring coefficient and low friction. Therefore, a tensile spring of $k=0.004 \mathrm{~N} / \mathrm{mm}$ was connected on the opposite side to the comparator. The movements formed by the effect of the friction force were measured by this method.

Table 1. Chemical composition of journal materials (wt \%).

\begin{tabular}{lcccccc}
\hline Material & $\mathrm{C}$ & $\mathrm{Si}$ & $\mathrm{Mn}$ & $\mathrm{P}$ & $\mathrm{S}$ & $\mathrm{Fe}$ \\
\hline SAE1050 & 0.51 & 0.3 & 0.7 & 0.04 & 0.05 & Based \\
\hline
\end{tabular}



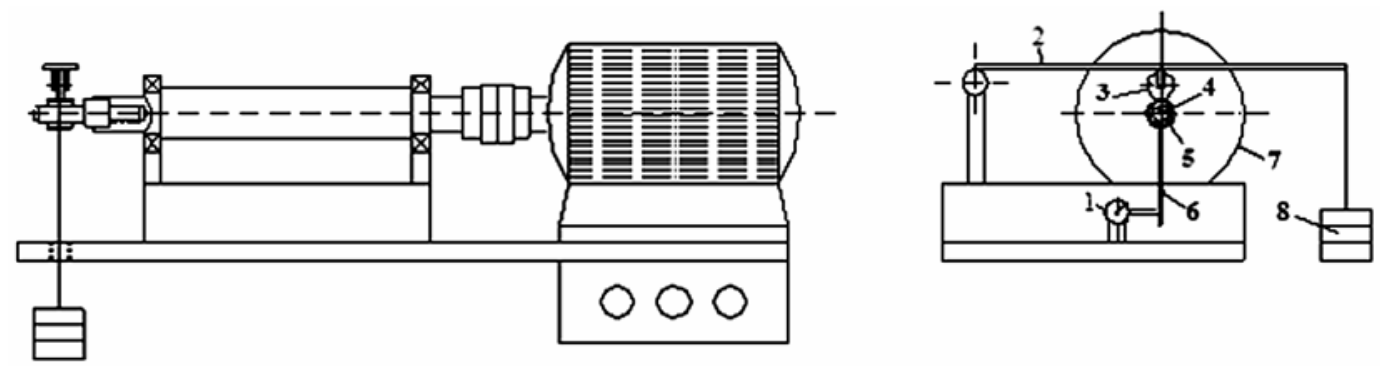

Figure 1. Radial journal bearing wear test rig (1. Comparator, 2. rigid bar, 3. load contact point (rolling bearing), 4. journal sample, 5. journal bearing samples, 6. plate bar, 7. motor, 8. loads).

Table 2. Chemical composition of bearing materials (wt \%).

\begin{tabular}{|c|c|c|c|c|c|c|c|c|c|c|c|}
\hline Materials & $\mathrm{Sn}$ & $\mathrm{Pb}$ & $\mathrm{Sb}$ & $\mathrm{Al}$ & $\mathrm{Cu}$ & $\mathrm{Mg}$ & $\mathrm{Si}$ & $\mathrm{Fe}$ & $\mathrm{Mn}$ & $\mathrm{Zn}$ & $\mathrm{Cr}$ \\
\hline CuSn10 & 10 & - & - & - & 90 & - & - & - & - & - & - \\
\hline $\mathrm{CuZn30}$ & - & - & - & - & 70 & - & - & - & - & 30 & - \\
\hline $\mathrm{ZnAl}$ & - & - & - & 5 & - & - & - & - & - & 95 & - \\
\hline $\mathrm{AlCuMg} 2$ & - & - & - & Based & $3 \cdot 8$ & $1 \cdot 2$ & 0.5 & 0.5 & $0 \cdot 3$ & $0 \cdot 25$ & $0 \cdot 1$ \\
\hline $\mathrm{SnPbCuSb}$ & 80 & 3 & 11 & - & 6 & - & - & - & - & - & - \\
\hline
\end{tabular}

Table 3. Roughness of bearing materials.

\begin{tabular}{lccccc}
\hline Roughness $(\mu \mathrm{m})$ & CuSn10 & CuZn30 & ZnAl & AlCuMg2 & SnPbCuSb \\
\hline Before wear & 1.61 & 2.5 & 1.01 & 3.51 & 1.33 \\
After wear & 1.03 & 1.85 & 1.12 & 5.21 & 2.62 \\
\hline
\end{tabular}

\section{Results and discussion}

\subsection{Surface roughness properties}

Values of surface roughness before and after wearing process are shown in table 3. These values of surface

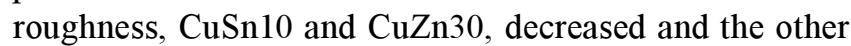
bearings increased after wear tests. These tests were performed on Mitutoyo-CE surface roughness test rig.

\subsection{Wear properties}

Friction coefficient, bearing temperature, bearing and journal weight loss values are given in figures $2-6$. The friction coefficient-time variation of bearings is shown in figure 2. The temperature-time variation of bearings is given in figure 3 . The wear losses of bearing-time variation of bearings are shown in figure 4 . The wear losses of journal-time variation of bearings are shown in figure 5 . The wear rate values of bearings depending on materials are shown in figure 6 . Friction coefficient was determined as a function of normal and friction force. The highest friction coefficients and bearing temperatures occurred in CuSn 10 and CuZn30 bearings, whereas the lowest friction coefficients and bearing wear losses occurred in other $\mathrm{ZnAl}, \mathrm{AlCuMg} 2$ and $\mathrm{SnPbCuSb}$ bearings. The highest journal weight loss occurred in $\mathrm{CuZn} 30$ and $\mathrm{AlCuMg} 2$ bearings, whereas the lowest journal wear loss occurred in $\mathrm{ZnAl}$ and $\mathrm{SnPbCuSb}$ bearings. The highest bearing wear rate occurred in $\mathrm{CuSn} 10$ and $\mathrm{CuZn} 30$ bearings, while the lowest bearing wear rate occurred in ZnAl bearing.

Pürçek (1994), Pürçek et al (1999), Savaşkan et al (2002) and Çuvalcı and Baş (2004) investigated tribological properties of $\mathrm{Zn}-\mathrm{Al}$ based journal bearings. They reported that these bearings had better tribological properties than those of bronze bearings. They determined the friction coefficient as $\sim 0.02$ at zinc-aluminum bearings. Rapoport et al (2002) and Gronostajski et al (2002) determined the friction coefficient of $\sim 0.08$ in bronze bearings. Türk et al (2007) determined the friction coefficient of $\sim 0.25$, wear rate of $25 \mathrm{mg} / \mathrm{km}$ in SAE 660 bronze bearings at $0.5 \mathrm{~m} / \mathrm{s}$ sliding speed and $30 \mathrm{~N}$ loads. In these studies, they reported that the wear rate increased with increasing applied load, and decreased with increasing sliding distance.

The differences in our results and those of other previous studies may be attributed to the fact that their materials were different from our materials. In addition, our results show that radial journal bearing test rig gives more accurate measurements. 


\subsection{Mechanical properties}

Mechanical properties of copper based bronze, brass and aluminum based duralumin bearing materials generally occurred than those of zinc based zamac and tin-lead based white metal bearing materials. Hardness of these bearing specimens was found to be around $100 \mathrm{HB}$. Results of mechanical tests are given in table 4 .

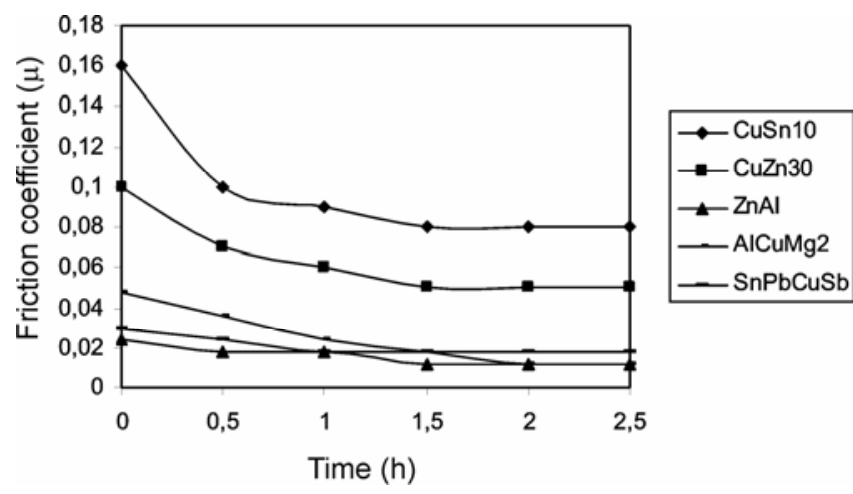

Figure 2. Friction coefficient-time variation of metal bearings.

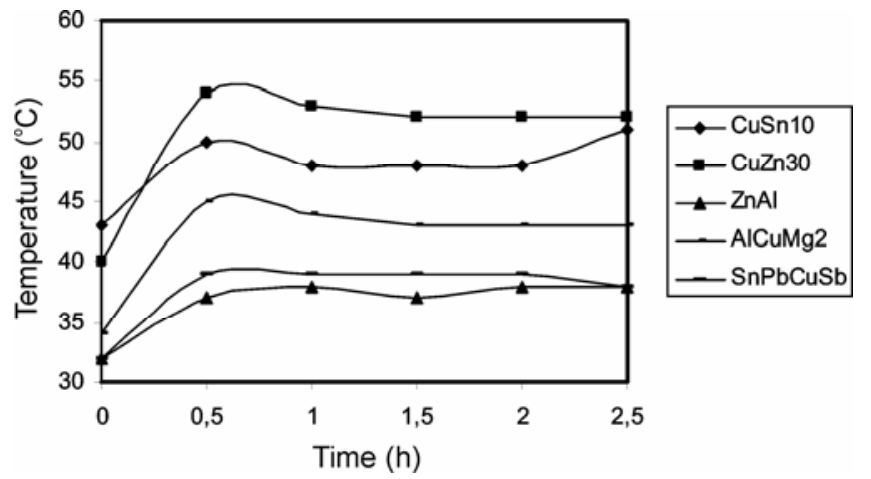

Figure 3. Temperature-time variation of metal bearings.

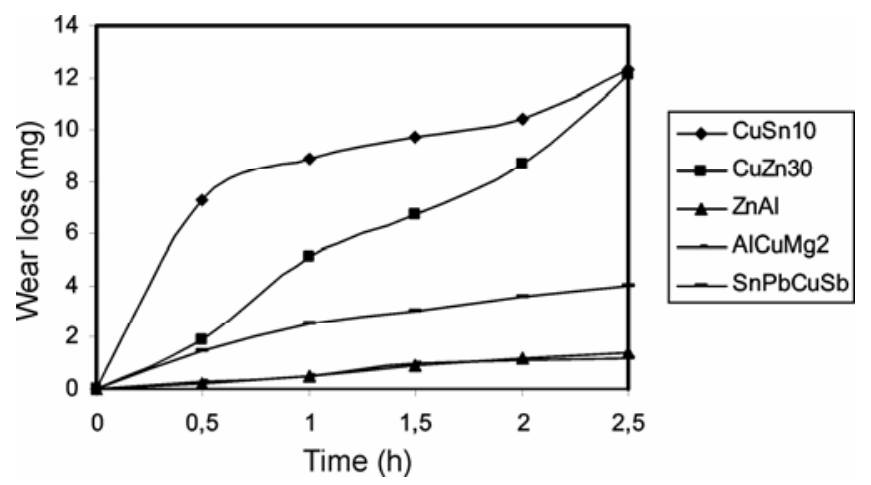

Figure 4. Wear losses bearing-time variation of metal bearings.

\subsection{Microstructure properties}

The wear surfaces in the specimens were examined using the optical (Hund Wetzlar CCD-290) and scanning electron microscope (Jeol JSM-6060). Microstructures of wear surface of metal bearings are presented in figure 7. SEM microstructures of wear surfaces of metal bearings are shown in figure 8 . Homogen and small wear tracks were present in bronze bearing, and big wear tracks occurred in brass bearing. Microfractures occurred in zamac bearing. Huge wear tracks occurred in duralumin bearing due to different element phases. Wear tracks occurred apparently on friction orientation in white metal bearing (figures 7-8).

Pürçek (1994), Pürçek et al (1999), Savaşkan et al (2002) and Çuvalcı and Baș (2004) observed micro fractures in $\mathrm{Zn}$ based bearings. They have observed big wear tracks in bronze bearings. Rapoport et al (2002), Gronostajski et al (2002) and Türk et al (2007) have observed homogen and small wear tracks in bronze bearings. In this study, similar wear tracks were observed at medium loads.

SEM microstructure of tensile fracture surfaces of metal bearing materials are shown in figure 9 . As can be seen in tensile fracture surfaces, fractures in bronze, brass

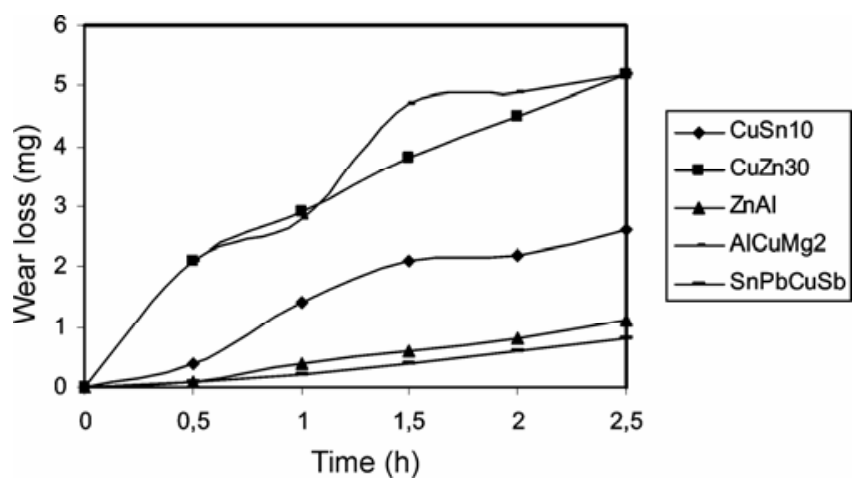

Figure 5. Wear losses journal-time variation of metal bearings.

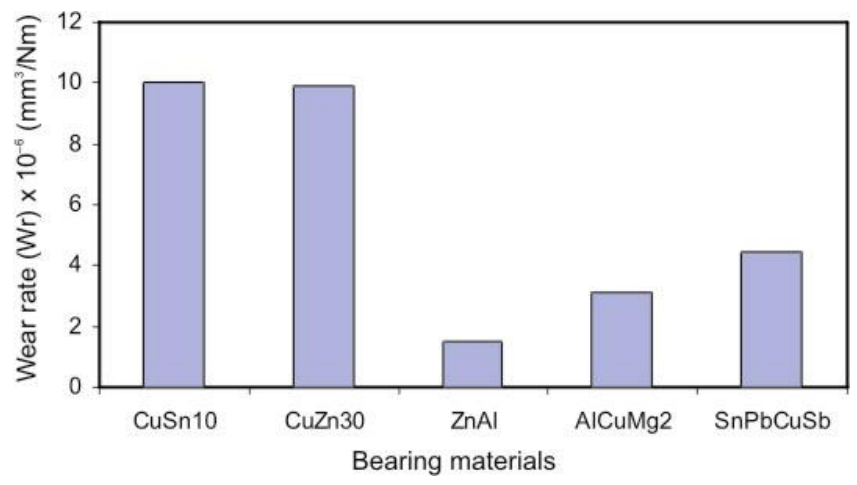

Figure 6. Comparison of wear rates of bearing materials. 
Table 4. Mechanical properties of bearing materials.

\begin{tabular}{lccccccrrr}
\hline & $\begin{array}{c}\text { Yield } \\
\text { strength, }\end{array}$ & $\begin{array}{c}\text { Tensile } \\
\text { strength, } \\
R_{\mathrm{m}}(\mathrm{MPa})\end{array}$ & $\begin{array}{c}\text { Break } \\
\text { strength, } \\
\sigma_{\mathrm{b}}(\mathrm{MPa})\end{array}$ & $\begin{array}{c}\text { Elongation } \\
(\% \varepsilon)\end{array}$ & $\begin{array}{c}\text { Compressive } \\
\text { strength } \\
\left(\sigma_{\mathrm{c}}\right)(\mathrm{MPa})\end{array}$ & $\left.\begin{array}{c}\text { Notch } \\
\text { impact } \\
\text { strength }(\mathrm{J})\end{array}\right) \begin{array}{c}\text { Bending } \\
\text { angle }\left(\alpha^{0}\right)\end{array}$ & $\begin{array}{c}\text { Hardness } \\
(\mathrm{HB})\end{array}$ & $\begin{array}{c}\text { Radial strength } \\
\text { fracture } \\
\left(\sigma_{\mathrm{rf}}\right)(\mathrm{MPa})\end{array}$ \\
\hline CuSn10 & 260 & 370 & 280 & 16 & 1200 & 16 & 125 & 100 & 83 \\
CuZn30 & 450 & 500 & 480 & 16 & 1000 & 14 & 140 & 120 & 105 \\
ZnAl & 190 & 210 & 200 & 3 & 750 & 3 & 180 & 70 & 16 \\
AlCuMg2 & 205 & 340 & 320 & 23 & 668 & 50 & 135 & 84 & 81 \\
SnPbCuSb & 70 & 100 & 100 & $3 \cdot 5$ & 224 & 3 & 180 & 30 & 3 \\
\hline
\end{tabular}
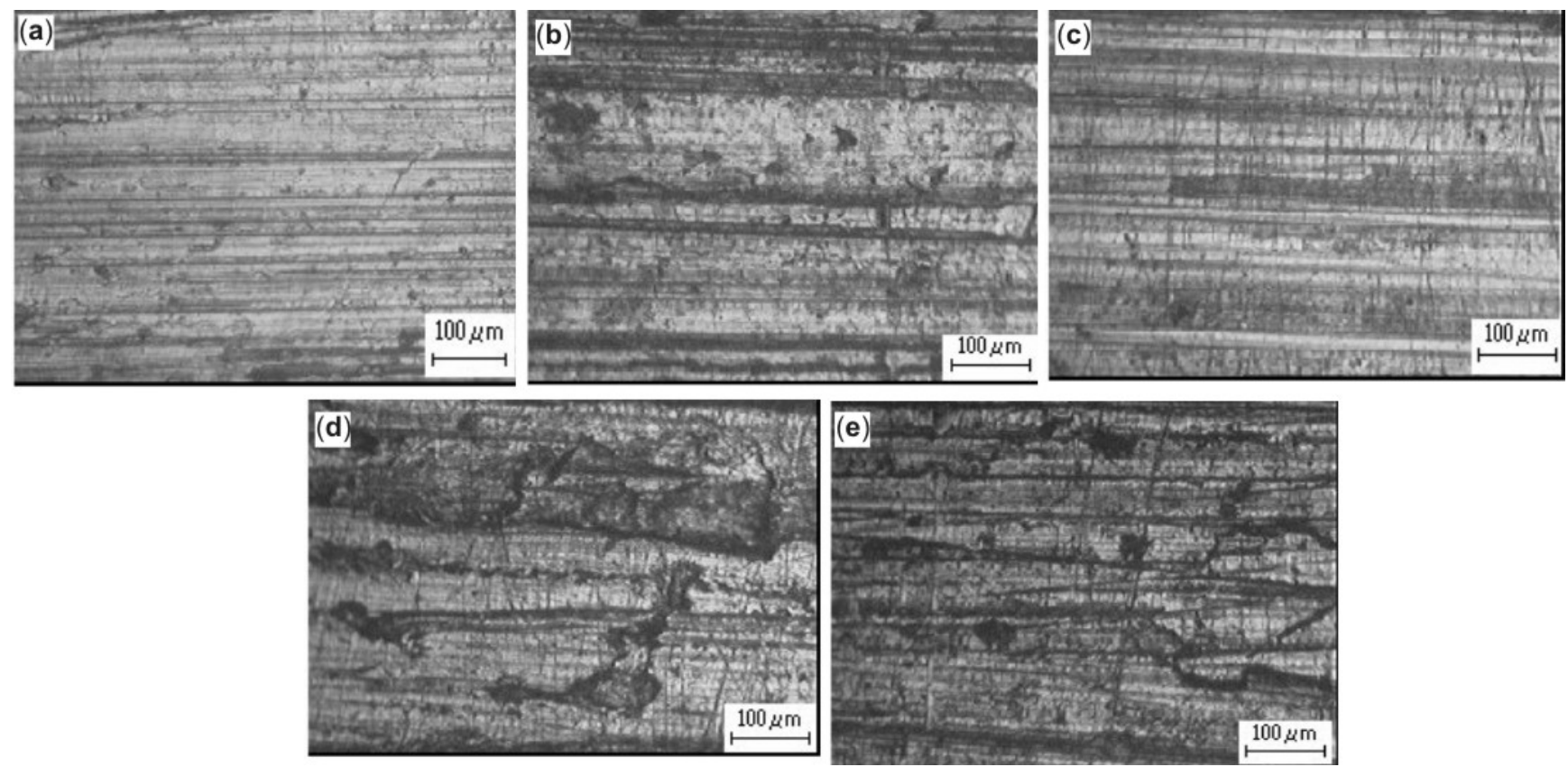

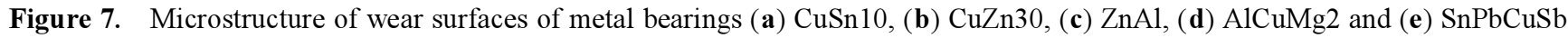
$(\times 100)$.
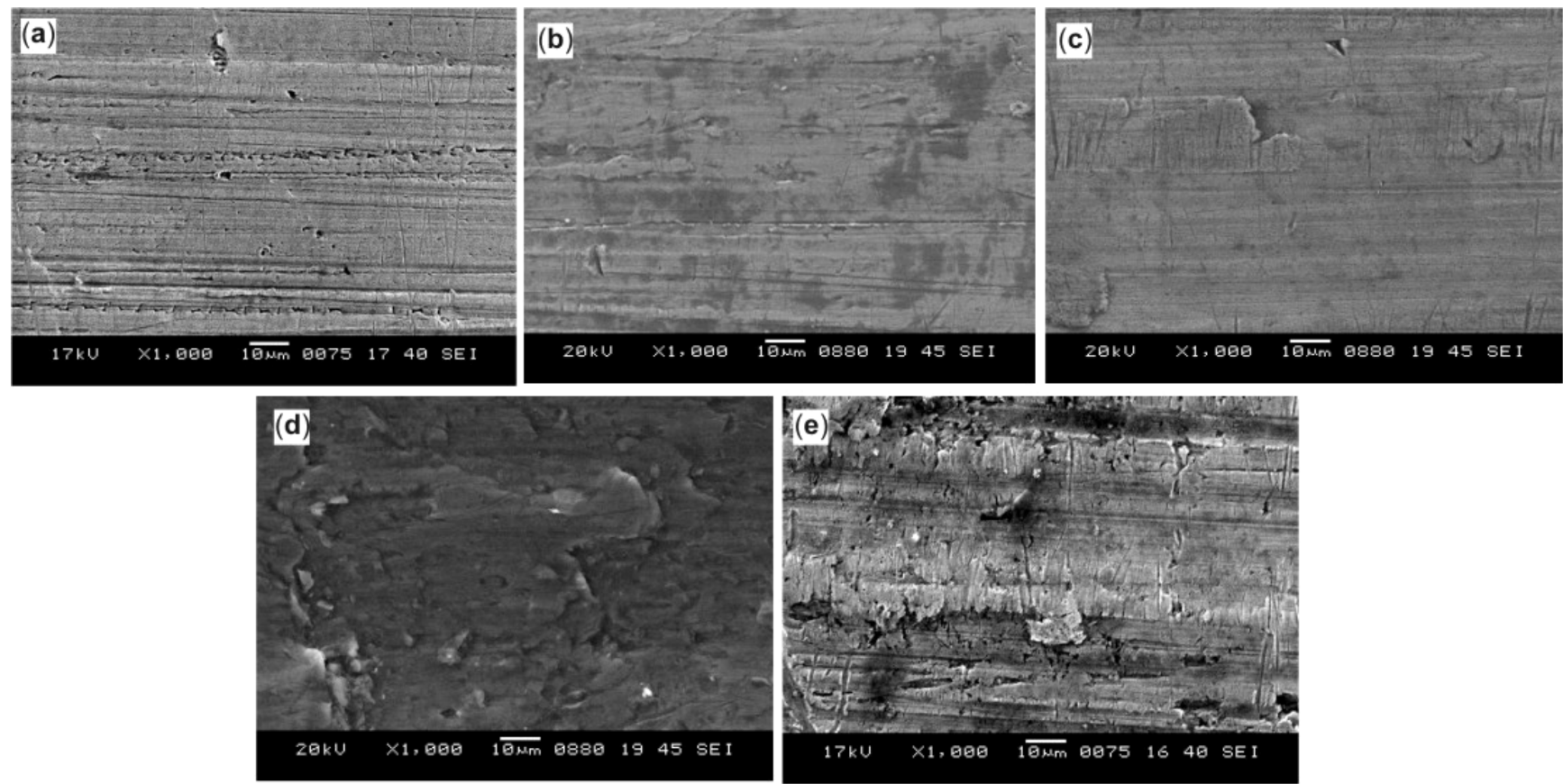

Figure 8. SEM microstructure of wear surface of metal bearings: (a) CuSn10, (b) CuZn30, (c) $\mathrm{ZnAl},(\mathbf{d}) \mathrm{AlCuMg} 2$ and (e) $\mathrm{SnPbCuSb}(\times 1000)$. 

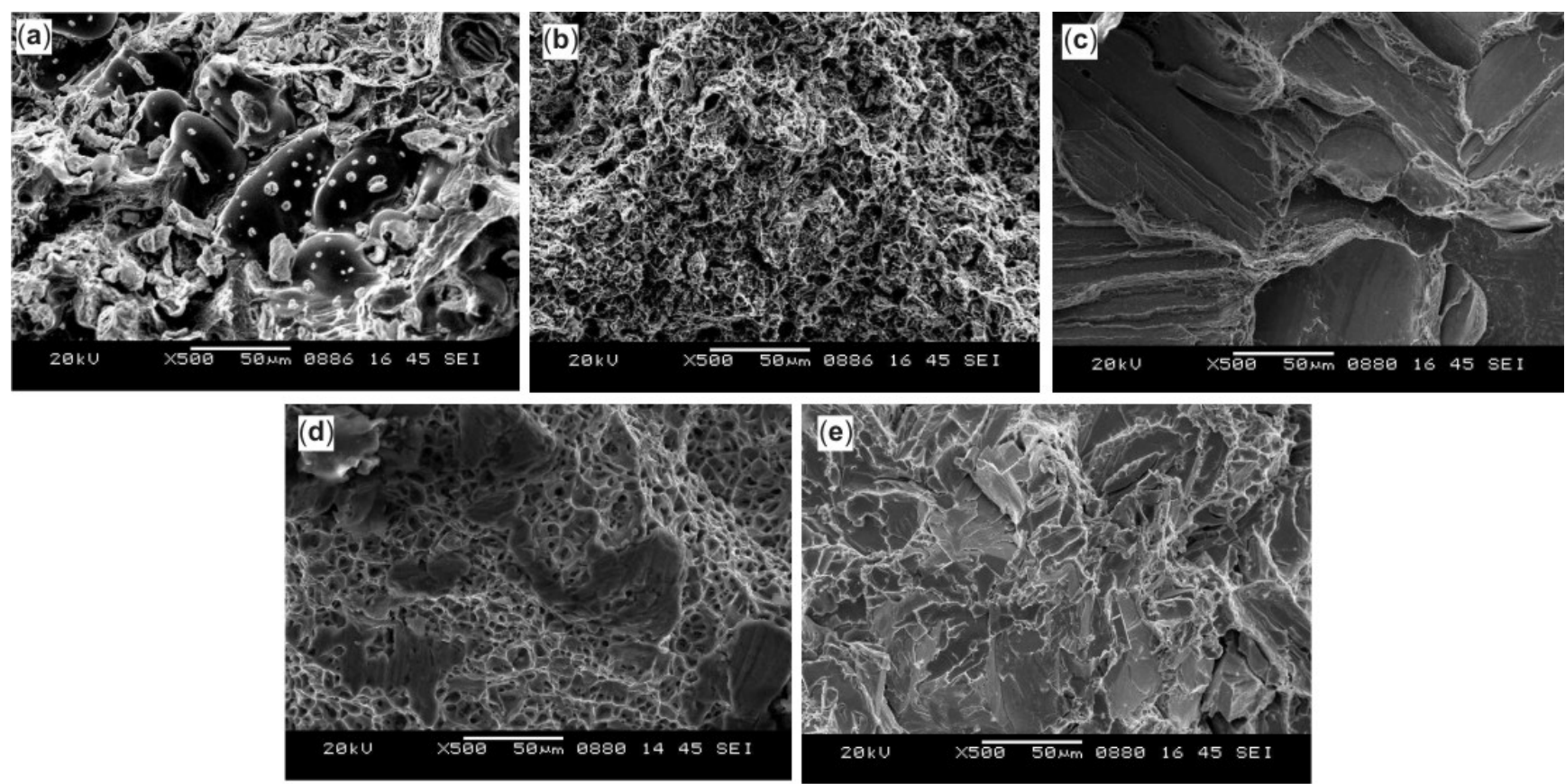

Figure 9. SEM microstructure of tensile fracture surface of metal bearing materials: (a) CuSn10, (b) CuZn30, (c) ZnAl, (d) $\mathrm{AlCuMg} 2$ and $(\mathbf{e}) \mathrm{SnPbCuSb}(\times 500)$.

and duralumin bearing materials occurred as thinly grained, while zamac and white metal bearing materials had thick fractures.

\section{Conclusions}

We conclude that journal bearings manufactured from metal based materials may be effectively used in the industry due to better tribological and mechanical properties. In this study, tribological and mechanical properties of journal bearings manufactured by metals were investigated. The following conclusions can be drawn:

(I) Post wear values of surface roughness decreased in $\mathrm{CuSn} 10$ and $\mathrm{CuZn} 30$ and increased in other bearings.

(II) The highest friction coefficient and bearing temperature occurred in $\mathrm{CuSn} 10$ and CuZn30 bearings, whereas the lowest friction coefficient and bearing weight loss occurred in other $\mathrm{ZnAl}, \mathrm{AlCuMg} 2$ and $\mathrm{SnPbCuSb}$ bearings. The highest journal weight loss occurred at $\mathrm{CuZn} 30$ and $\mathrm{AlCuMg} 2$ bearings.

(III) The highest bearing wear rate occurred in CuSn10 and CuZn30 bearings, and the lowest bearing wear rate occurred in $\mathrm{ZnAl}$ bearing.

(IV) The mechanical properties of CuSn10, CuZn30 and $\mathrm{AlCuMg} 2$ bearing materials were better than those of $\mathrm{ZnAl}$, and $\mathrm{SnPbCuSb}$ bearing materials.

\section{References}

Atik E, Ünlü B S and Meriç C 2001 Design of radial journal bearing wear test rig, Conference of Mach. Mater. and Technol. (in Turkish) (Turkey), 2 pp 98-103
Backensto A B 1990 Effects of lubricants on the properties of copper-tin powders and compacts, Advances in $P / M$, Proc. of PM conf., APMI, N. Jersey, pp 303-314

Barhust R J 1989 Guidelines for designing zinc alloy bearingsa technical manual, Soc. Auto Eng., Paper no: 880289

Çuvalcı H and Baş H 2004 Tribol. Int. 37433

Dawson D 1998 History of tribology (London: Profes. Eng. Pub.), p. 768

Enomoto Y and Yamamoto T 1998 Trib. Lett. 513

Eyre T S 1991 Surf. Eng. 7143

Gronostajski J, Chmura W and Gronostajski Z 2002 J. Mater. Proc. Technol. 125-126 483

Hanna M D, Carter J T and Rashid M S 1997 Wear 203-204 11

Haque M M and Sharif A 2001 J. Mater. Proc. Technol. 118 69

Harmsen M, Laufer E and Masounave J 1996 Wear 192128

Lepper K, James M, Chashechkina M J and Rigney D A 1997 Wear 203-204 46

Liu Y L, Kang S B and Kim H W 1999 Mater. Lett. 41267

Niinomi M, Fukunaga K and Takeda J 1997 Mater. Sci. Forum 331-337 1519

Paulo D 2000 J. Mater. Proc. Technol. 100273

Prasad B K 1997 Metal. Trans. 28809

Prasad S V and Rohatgi P K 1987 J. Metals 22

Pratt G C 1973 Inter. Metall. Rev. 1823

Pürçek G 1994 Investigation of tribological properties $\mathrm{Zn}-\mathrm{Al}$ based journal bearings, Master thesis, Karadeniz Technical University, Trabzon, Turkey (in Turkish)

Pürçek G, Küçükömeroğlu T and Savaşkan T 1999 Eng. and Mach. 44335

Rapoport L, Leshchinsky V, Lvovsky M, Labsker I, Volovik Y and Tenne R 2002 Tribol. Int. 3547

Savaşkan T, Pürçek G and Murphy S 2002 Wear 252693

Schatt W and Wieters K P 1997 Powder metallurgy, Proc. mater. EPMA (Shrewsbury, UK) p. 492 
Schmidt R F and Schmidt D G 1993 Selection and application of copper alloy castings, ASM handbook II, pp 34463557

Sharma S C, Girish B M, Kamath R and Satish B M 1998 Wear 219162

Türk A, Kurnaz C and Şevik H 2007 Mater. Design 28 1889
Ünlü B S 2004 Determination of usability of boronized ferrous based materials as bearing and tribological properties in journal bearings, $\mathrm{PhD}$ thesis, Celal Bayar University, Manisa, Turkey (in Turkish)

Ünlü B S and Atik E 2007 Mater. Des. 28973

Upadhyaya A N, Mishra S and Ojha S N 1997 J. Mater. Sci. 323227

Zeren A 2007 Mater. Des. 282344 